Article

\title{
Investigation of the Concepts to Increase the Dew Point Temperature for Thermal Energy Recovery from Flue Gas, Using Aspen ${ }^{\circledR}$
}

\author{
Nataliia Fedorova ${ }^{1,2}{ }^{(}$, Pegah Aziziyanesfahani ${ }^{1}$, Vojislav Jovicic ${ }^{1,2, *(1)}$, Ana Zbogar-Rasic ${ }^{1}$, \\ Muhammad Jehanzaib Khan ${ }^{1}$ and Antonio Delgado ${ }^{1,2}$ \\ 1 Institute of Fluid Mechanics (LSTM), Friedrich-Alexander University (FAU), 91058 Erlangen, Germany; \\ nataliia.fedorova@fau.de (N.F.); pegah.aziziyan@gmail.com (P.A.); ana.zbogar-rasic@fau.de (A.Z.-R.); \\ muhammad.j.khan@fau.de (M.J.K.); antonio.delgado@fau.de (A.D.) \\ 2 Erlangen Graduate School in Advanced Optical Technologies (SAOT), 91054 Erlangen, Germany \\ * Correspondence: vojislav.jovicic@fau.de; Tel.: +49-9131-85-29492
}

Received: 31 March 2019; Accepted: 23 April 2019; Published: 26 April 2019

\begin{abstract}
Thermal energy of flue gases (FG) dissipating from industrial facilities into the environment, constitute around $20 \%$ of the total dissipated thermal energy. Being part of the FG, water vapour carries thermal energy out of the system in the form of the latent heat, which can be recovered by condensation, thus increasing the overall efficiency of an industrial process. The limiting factor in this case is the low dew point temperature (usually $40-60^{\circ} \mathrm{C}$ ) of the water vapour in the FG. The increase of the dew point temperature can be achieved by increasing the water content or pressure. Taking these measures as a basis, the presented work investigated the following concepts for increasing the dew point temperature: humidification of the flue gas using water, humidification using steam, compression of the FG and usage of the steam ejector. Modelling of these concepts was performed using the commercial software Aspen ${ }^{\circledR}$. The humidification of the FG using water resulted in the negligible increase in the dew point $\left(3^{\circ} \mathrm{C}\right)$. Using steam humidification the temperatures of up to $92{ }^{\circ} \mathrm{C}$ were reached, while the use of steam ejector led to few degrees higher dew point temperatures. However, both concepts proved to be energy demanding, due to the energy requirements for the steam generation. The FG compression enabled the achievement of a $97^{\circ} \mathrm{C}$ dew point temperature, being both energy-efficient and exhibiting the lowest energy cost.
\end{abstract}

Keywords: thermal energy recovery; flue gas; dew point temperature; condensation; Aspen ${ }^{\circledR}$

\section{Introduction}

The dissipation of thermal energy from industrial facilities during production processes is and has been a challenging issue worldwide. Flue gases from industrial processes constitute around $20 \%$ of the total dissipated energy [1-3]. Water vapour, as a part of the flue gas, carries latent heat, which can be recovered. Depending on the industry, flue gas temperatures vary from 120 to $200{ }^{\circ} \mathrm{C}$ [4-6], whereas water vapour content can be up to $90 \%$ vol. For example, as presented in Table 1 , in the flue gas of natural gas-fired boilers $20 \%$ vol accounts for the water vapour $[3,6]$, while in the potato crisps manufacturing its content is around $40 \%$ vol [5]. Unlike the flue gas from the drying processes, which can contain up to $90 \%$ of the water vapour [7], most of the flue gases from the other processes have a much lower water vapour content. Baking, textile, pulp and paper industries have a potential for the recovery of thermal energy from the flue gas, due to the large quantity of water vapour in their flue gases and massive production rates [8-10]. 
Table 1. Composition of different industrial flue gases.

\begin{tabular}{ccccc}
\hline Industry & $\mathbf{H}_{\mathbf{2}} \mathbf{O}[\%]$ & $\mathbf{C O}_{2}[\%]$ & $\mathbf{N}_{\mathbf{2}}[\%]$ & $\mathbf{O}_{2}[\%]$ \\
\hline Potato crisps manufacturing [5] & 41.1 & 5 & 50.6 & 3.3 \\
Natural gas-fired boiler [11] & $18-20$ & $8-10$ & $67-72$ & $2-3$ \\
Coal-fired boiler [11] & $8-10$ & $12-14$ & $72-77$ & $3-5$ \\
\hline
\end{tabular}

The difference in the concentration levels of water vapour in flue gases of different processes is in general less influenced by the type of the fired fuel and more by the amount of the water vapour originating from the process itself. In many of the processes, especially in the food industry, a single fan at the outlet of the system evacuates all the gases from the system. In this way, the flue gas originating from the burners is commonly mixed with the gases originating from the processed product and also often with the excess air, sucked into the system from the surrounding. In the processes like drying or baking, the raw material (paper, potato, dough, etc.) can release significant amounts of the water vapour leading to the increase of the overall water vapour concentration in the flue gas at the outlet of the system.

The higher the amount of water vapour in the flue gas, the more latent heat can be recovered from it. Therefore, this issue is essentially relevant for industries with water vapour-rich flue gases. Recovering sensible and latent heat by water vapour condensation from the flue gas has been reported by different sources as a promising way to improve the total energy efficiency by around $10 \%[3,7,12]$. Herewith come economic and environmental benefits.

A traditional unit for thermal energy recovery from the flue gas is a gas-to-liquid condensing heat exchanger. During the heat exchange with the cooling liquid, the flue gas temperature is reduced below the dew point, so that the water vapour is condensed and the release of the latent and sensible heat occurs. Porous and non-porous gas separation membranes have been actively developed for the simultaneous heat and water recovery from the flue gas $[7,13]$. The growing interest for the thermal energy recovery application is connected to the Organic Rankine Cycle (ORC) technology for generation of electricity and absorption refrigerator (AR) technology for driving cooling processes [5,14-16].

One of the factors limiting the application of the aforementioned recovery systems is the low dew point temperature of the water vapour in the flue gas, usually in the range of $40-60{ }^{\circ} \mathrm{C}$, i.e., the temperature increase of the working liquid is not sufficient to be used as process heat within the production cycle. Increasing the dew point temperature can help to upgrade the temperature level of working fluids and to reach higher energy efficiencies. For example, in AR the increase of the thermal source temperature from $80^{\circ} \mathrm{C}$ to $86^{\circ} \mathrm{C}$, increases the coefficient of performance by $7 \%[17,18]$.

On the example of the condensing heat exchangers (HE) as a recovery technology, the increase of the dew point temperature of the water vapour contained in the flue gas leads to obtaining the condensate and the cooling water at the higher temperature level. In this way, these otherwise waste streams can be further used within an industry as process heat for a wide range of applications, e.g., space heating, heating, ventilation and air-conditioning (HVAC) of office areas, as sanitary water, for washing and cleaning in the production areas, for preparation of dough in the case of a baking industry, for preheating of fuel and combustion air in the case of a power generation industry [19-21], etc. Other industry-dependent in-plant demands for recovered thermal energy should be generally determined by conducting a full energy audit.

Process modelling is one of the ways to analyse the thermal energy recovery from industrial processes. The licensed software Aspen Plus ${ }^{\circledR}$ and Aspen ${ }^{\circledR}$ HYSYS $^{\circledR}$ find applications in modelling of chemical, biological and physical processes. It enables to model complex processes using simple models with built in unit operation models (e.g., heat exchangers, columns, reactors, mixers, splitters, etc.) and property methods.

The Aspen ${ }^{\circledR}$ software is a widely used tool for analysing system performances. Jana et al. [22] used it to model the utilisation of the waste heat by means of a condensing HE for the post-combustion $\mathrm{CO}_{2}$ capture. Luyben [23] simulated HEs with phase changes, namely a condenser and an evaporator, 
for low-level energy recovery with n-hexane as a working fluid. Duan et al. [24] analysed coal gasification, which included a gasifier and a boiler to recover steam and blast furnace slag. Ishaq et al. [25] modelled a trigeneration system for electricity, hydrogen and fresh water production from the flue gas of a glass melting furnace. Mazzoni et al. [26] proposed ORC plant arrangements, based on the turbo-expander pumping system and internal regeneration processes for low grade waste thermal energy recovery, aiming to improve the plant efficiency and to reduce the cooling load on the condenser.

The motivation behind the presented research was to investigate the concepts, leading to the increase of the dew point temperature of the water vapour contained in the flue gas (preferably above $80^{\circ} \mathrm{C}$ ), in order to recover its latent and sensible heat. It is generally known, that the increase of the dew point temperature can be achieved through the increase of the water vapour share in the flue gas or through the increase of the flue gas pressure. Taking these measures as a basis, the presented work investigated the following concepts for increasing the dew point temperature: humidification of the flue gas using water, humidification of the flue gas using steam, compression of the flue gas and the usage of the steam ejector.

The investigated models were developed in Aspen Plus ${ }^{\circledR}$ V8.8 and Aspen ${ }^{\circledR}$ HYSYS ${ }^{\circledR}$ V8.8. The condensing shell-and-tube HE was chosen as a thermal energy recovery technology. Under examination was the influence of the dew point temperature of the water vapour in the flue gas and the flow rate of the cooling water in the HE on the amount of the recovered thermal energy, the temperature of the cooling water at the HE outlet and the flow rate of the condensate. In order to analyse each concept from the economic point of view, the energy cost was estimated.

\section{Model Description and Methodology}

Within the presented work, four concepts leading to the increase of the dew point temperature of the water vapour in the flue gas were investigated, by means of the aspenONE ${ }^{\circledR}$ Engineering Suite:

1. Humidification of the flue gas using water (Aspen Plus ${ }^{\circledR}$ V8.8)

2. Humidification of the flue gas using steam (Aspen Plus ${ }^{\circledR}$ V8.8)

3. Compression of the flue gas (Aspen Plus ${ }^{\circledR}$ V8.8)

4. Usage of the steam ejector (Aspen ${ }^{\circledR}$ HYSYS ${ }^{\circledR}$ V8.8)

The steady state process modelling based on the energy balance was performed for each concept. The Peng-Robinson equation of state was chosen as a physical property method, commonly used in the gas processing industry. The investigated models were established under the following assumptions: the flue gas follows the ideal gas behaviour, the flue gas is composed of noncondensable (dry air) and condensable gas (water vapour), which is the approach followed in many studies [3,6,27].

In the tested concepts, the parameters of the flue gas at the outlet of the industrial baking oven were measured and used for calculations. The flue gas at the exit of an industrial baking oven had the temperature of $120^{\circ} \mathrm{C}$ and the pressure of $1.01 \mathrm{bar}$, with the dew point temperature of $67^{\circ} \mathrm{C}$. The flue gas mass flow rate was $276.2 \mathrm{~kg} / \mathrm{h}$, with the air mass flow rate of $229.4 \mathrm{~kg} / \mathrm{h}$ ( $83 \%$ mas) and $46.8 \mathrm{~kg} / \mathrm{h}$ for water vapour (17 \%mas).

\subsection{Concept 1: Humidification of the Flue Gas Using Water}

Modelling of the concept with humidification of the flue gas using water, shown in Figure 1, is realised by adding WATER $\left(95^{\circ} \mathrm{C}\right.$ and $\left.1.01 \mathrm{bar}\right)$ into the flue gas stream EXGAS. During perfect mixing (MIXER unit model) water evaporates using the thermal energy of the flue gas. Evaporation of the sprayed water increases the concentration of the water vapour in the flue gas stream and consequently its partial pressure and the GASIN dew point temperature.

The humidified flue gas stream GASIN leaves the mixer and is cooled in the counter-current heat exchanger HE (HEATX model) by the flow of WATERIN, supplied at a temperature of $60^{\circ} \mathrm{C}$ and pressure of 1.01 bar. During the heat exchange between the two streams, the water vapour from the 
humidified flue gas stream condenses at constant pressure, and the condensate CONDENS occurs. The heated cooling water WATEROUT and the cooled dried flue gas GASOUT leave the HE.

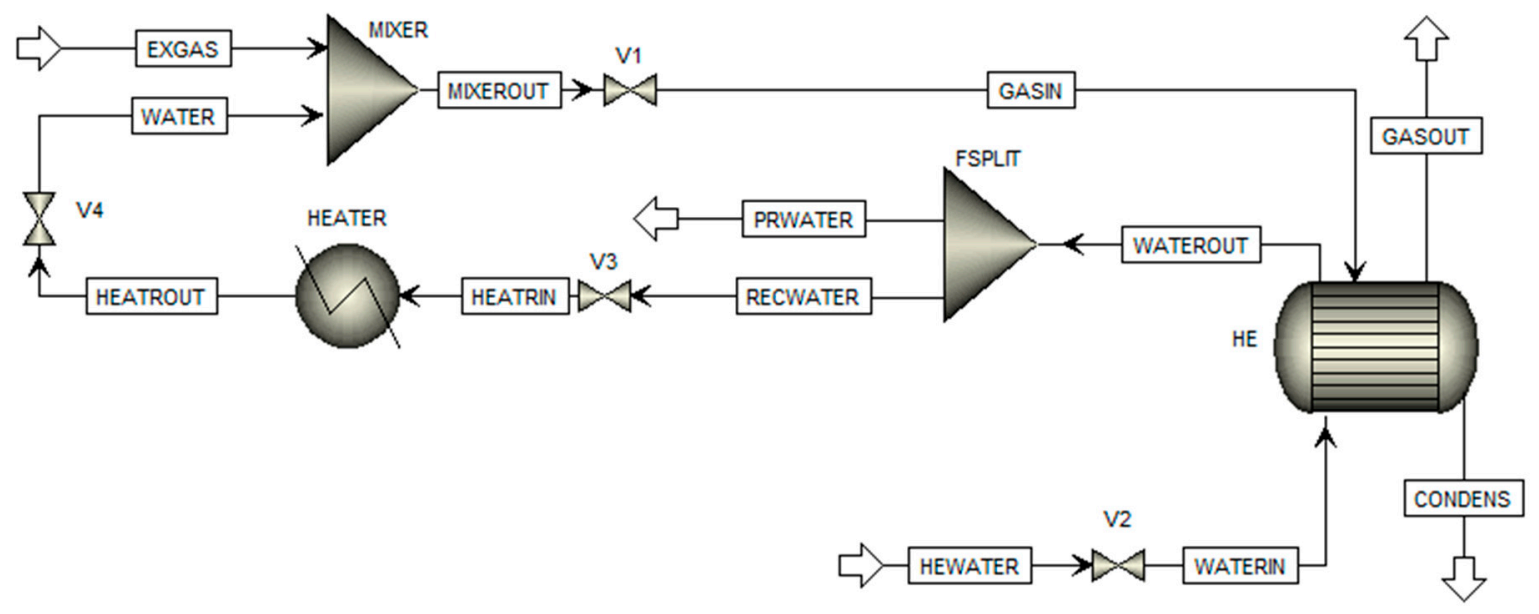

Figure 1. Flowsheet for the humidification of the flue gas using water.

The heated cooling water is then separated in the stream splitter (FSPLIT model), depending on the required amount of water for the GASIN dew point temperature increase. The first part, the water for further recycling RECWATER, is heated in the HE (HEATER model), in order to be sprayed into the MIXER. The second part, the process water PRWATER, can be used in other applications required within the industry, and is considered as the useful process stream, obtained from the thermal energy recovery cycle of the flue gas.

\subsection{Concept 2: Humidification of the Flue Gas Using Steam}

In the process model of the second investigated concept, the steam generator SG (HEATER model) is provided for the production of STEAM $\left(120^{\circ} \mathrm{C}\right.$ and $\left.1.01 \mathrm{bar}\right)$. This steam is further used for humidification of the flue gas stream EXGAS, as presented in Figure 2. The recycling water in the concept RECWATER passes through the SG, in order to be evaporated. The other components are the same as in the previous model.

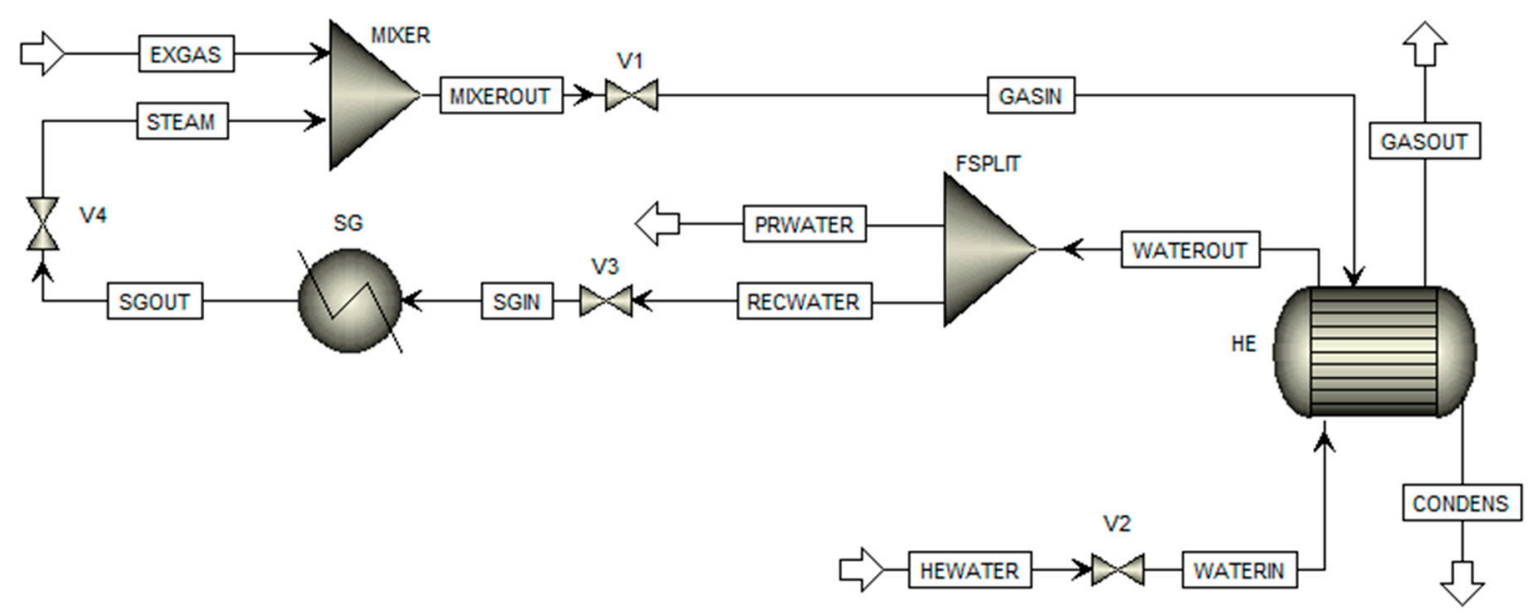

Figure 2. Flowsheet for the humidification of the flue gas using steam.

It is expected that in the case of the steam humidification, the higher GASIN dew point temperature can be reached, since there is no need to use the thermal energy of the flue gas for the evaporation of water, as in concept 1 . 


\subsection{Concept 3: Compression of the Flue Gas}

The third investigated concept is the compression of the flue gas, demonstrated in Figure 3. The flue gas stream EXGAS is directed to the compressor (COMPR model), where during the isentropic compression its temperature and pressure increase. The compressed flue gas stream GASIN is then led to the heat exchanger $\mathrm{HE}$, as in the previously described cases. The heated cooling water WATEROUT at the outlet of the HE is not needed further in the recovery process, thus it can be fully utilized as process heat for different applications within the industry.

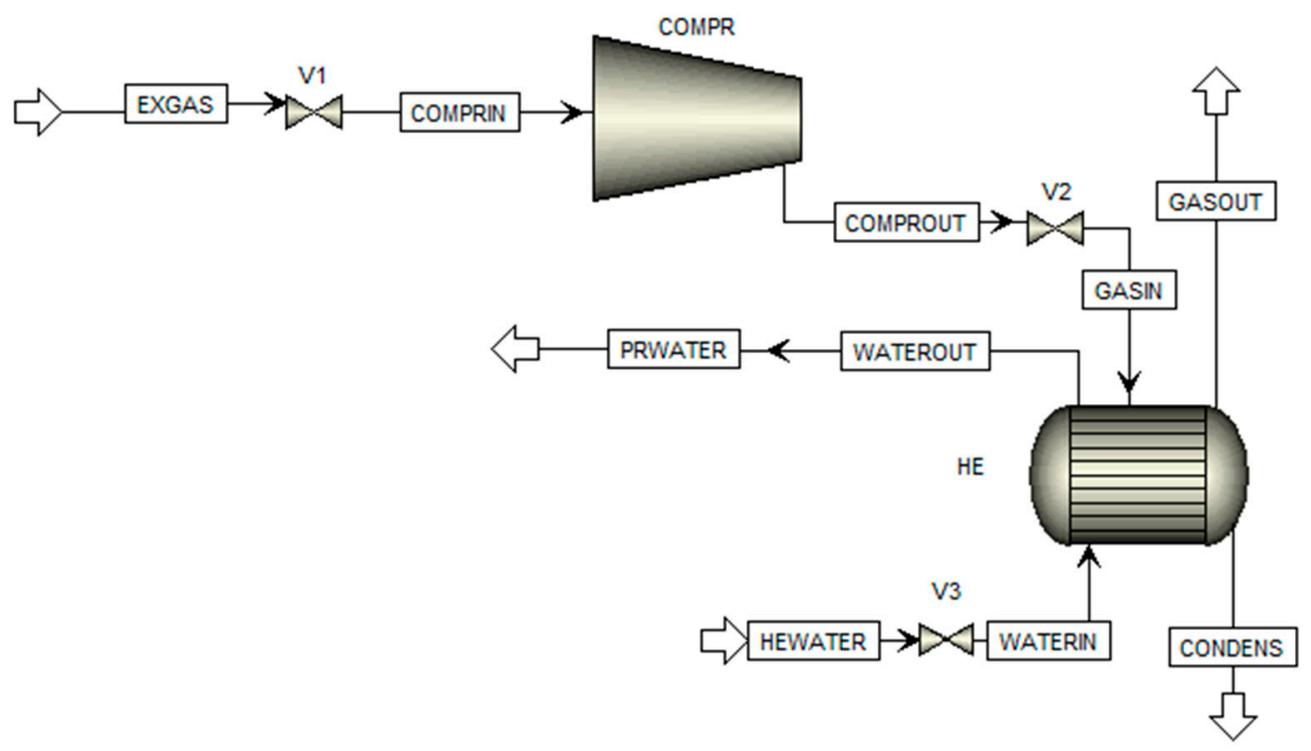

Figure 3. Flowsheet for the concept with the compression of the flue gas.

\subsection{Concept 4: Usage of the Steam Ejector}

Using the steam ejector leads to the GASIN dew point temperature increase, due to the simultaneous increase in the water content of the flue gas and its pressure, resulting from the geometry of the device. The flowsheet for concept 4 is given in Figure 4. The modelling was performed in the Aspen ${ }^{\circledR}$ HYSYS ${ }^{\circledR}$ software, since Aspen Plus ${ }^{\circledR}$ does not incorporate the steam ejector model. The other units are the same as in the previously described concepts.

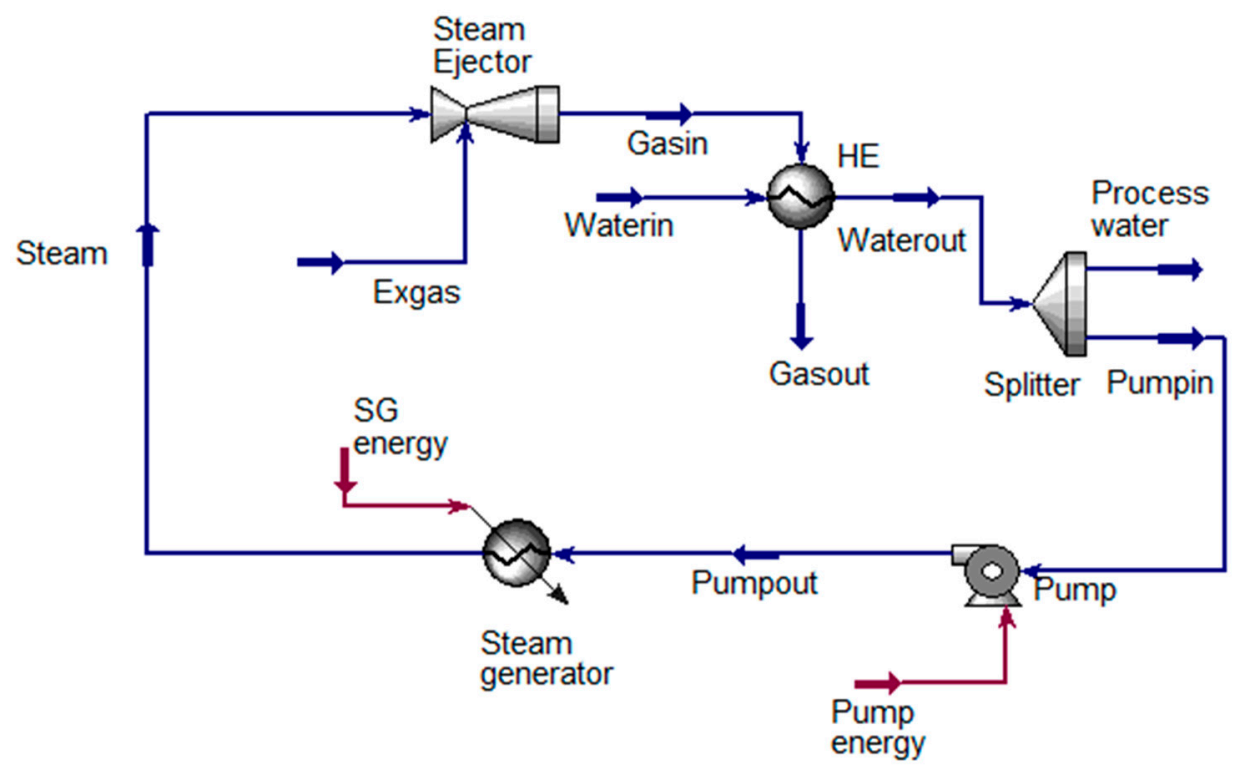

Figure 4. Flowsheet for the concept with the steam ejector. 
The flue gas stream EXGAS is introduced from the low pressure side of the STEAM EJECTOR (Ejector model), whereas STEAM as a motive fluid is supplied from the high-pressure side. The discharged stream GASIN is directed to the HE (Heat Exchanger model), where the water vapour condenses from the flue gas during water cooling by WATERIN. The heated cooling water WATEROUT is separated in the SPLITTER (Tee model) into two parts: (1) PUMPIN, recirculated to generate the high pressure steam, and (2) PROCESS WATER, utilized for the needs of the industry. Pressure of the water PUMPIN is increased in the PUMP (Pump model), and then the high pressure water PUMPOUT is directed to the STEAM GENERATOR (Heater model) to be evaporated at the constant pressure. The generated high pressure STEAM is led to the STEAM EJECTOR to humidify the flue gas.

\subsection{Heat Exchanger Design}

The shell-and-tube heat exchanger for extracting the thermal energy from the flue gas was designed using the Aspen Shell \& Tube Exchanger ${ }^{\mathrm{TM}}$. The following inlet parameters for the HE were used: physical properties of the inlet streams ( $T, p$, mass flow and composition), temperature change, pressure drops in the shell and the tube side and the fouling factors for each inlet fluid. The possible HE design, according to the given inlet parameters, coupled with the failure analysis was provided by the software. The suggested design was improved by trial-and-error calculations following Kern's method [28]. The HE with the key design parameters, shown in Table 2, was used for modelling of all the previously described concepts.

Table 2. Design parameters of the HE.

\begin{tabular}{ccccccc}
\hline $\begin{array}{c}\text { Shell OD } \\
(\mathbf{m m})\end{array}$ & $\begin{array}{c}\text { Tube OD } \\
(\mathbf{m m})\end{array}$ & $\begin{array}{c}\text { Tube Length } \\
(\mathbf{m m})\end{array}$ & $\begin{array}{c}\text { Tube } \\
\text { Pattern }\end{array}$ & $\begin{array}{c}\text { Number of } \\
\text { Tubes }\end{array}$ & $\begin{array}{c}\text { Baffle Spacing } \\
(\mathbf{m m})\end{array}$ & $\begin{array}{c}\text { Number of } \\
\text { Baffles }\end{array}$ \\
\hline 219 & 19 & 2700 & Triangular & 49 & 0.15 & 15 \\
\hline
\end{tabular}

The effectiveness of the heat exchanger was calculated using the Number of Transfer Units (NTU) method. The typical values for the reference case with the dew point temperature of $67^{\circ} \mathrm{C}$ lay in the range of $83-93 \%$ for the flow rate of cooling water of $400-2000 \mathrm{~kg} / \mathrm{h}$, respectively.

The allowable pressure drops were determined, based on the standard values given by Aspen ${ }^{\circledR}$, as $0.1 \mathrm{bar}$ and $0.2 \mathrm{bar}$ for the shell and the tube side, respectively. The fouling factor of $0.0003 \mathrm{~m}^{2} .{ }^{\circ} \mathrm{C} / \mathrm{W}$ for the cooling water and $0.0005 \mathrm{~m}^{2} \cdot{ }^{\circ} \mathrm{C} / \mathrm{W}$ for the flue gas were taken from the literature [29].

\subsection{Theoretical Calculations}

All the calculations and considerations in this work are related to one specific industrial facility, namely the natural gas fired, tunnel baking oven. The limitations related to the investigated facility (composition, temperature and flow rate of the flue gas, fluid parameters at the inlet/outlet of the process components, etc.) influence most of the obtained results. Therefore, it is imperative to perform the similar analysis for each specific system of interest with its unique properties.

Based on the parameters of the flue gas, previously listed in the preface to chapter two of this work, the inlet values for process modelling were determined by thermodynamic calculations. Few major ones are presented below with Equations (1)-(4). The used terminology can be found in Nomenclature.

Humidity ratio of an air-vapour mixture:

$$
x=\frac{m_{w}}{m_{\text {air }}}
$$

Partial pressure and density of water vapour in the flue gas:

$$
P_{w}=\frac{x \cdot P}{0.622+x}
$$




$$
\rho_{w}=\frac{P_{w}}{R_{w} \cdot T}
$$

Dalton's law for air-vapour mixtures:

$$
P=y_{\text {air }} P+y_{\text {vap }} P
$$

The dew point of the water vapour was taken from the thermodynamic tables for the saturated vapour pressure values $\left(P_{i}^{s}\right)$, calculated using Raoult's law:

$$
y_{i} P=x_{i} P_{i}^{s}
$$

The amount of the recovered thermal energy, representing the enthalpy difference between the flue gas at the HE inlet (GASIN stream) and at HE outlet (GASOUT stream), was calculated with Equations (6)-(8):

$$
\begin{gathered}
Q_{R E}=m_{\text {air }} \cdot\left(h_{\text {in }}-h_{\text {out }}\right) \\
h_{\text {in }}=\left(C_{p, \text { air }} \cdot t_{\text {gas }, \text { in }}\right)+x_{\text {in }}\left(C_{p, \text { vap }} \cdot t_{\text {gas }, \text { in }}+\Delta h_{\text {vap }}\right) \\
h_{\text {out }}=\left(C_{p, \text { air }} \cdot t_{\text {gas }, \text { out }}\right)+x_{\text {out }}\left(C_{p, \text { vap }} \cdot t_{\text {gas }, \text { out }}+\Delta h_{\text {vap }}\right)
\end{gathered}
$$

For each investigated concept described above (Figures 1-4), the energy gain and the energy demand were estimated. The energy dissipation in the pipelines between the system components was neglected. As energy gain (Equations (9)-(12)) was considered the case, when the temperature of the cooling water, of the flue gas and of the condensate at the HE outlet exceeded $t_{\text {washing. }}$. The temperature $t_{\text {washing }}$ was set to be $60^{\circ} \mathrm{C}$, based on the average temperature level useful for washing purposes within the production.

$$
\begin{gathered}
Q_{\text {gain }}=Q_{w, \text { out }}+Q_{g a s, \text { out }}+Q_{\text {condens }} \\
Q_{w, \text { out }}=m_{\text {prwater }} \cdot C_{p, w} \cdot\left(t_{w, \text { out }}-t_{\text {washing }}\right) \\
Q_{g a s, \text { out }}=m_{\text {gas,out }} \cdot C_{p, g a s} \cdot\left(t_{g a s, \text { out }}-t_{\text {washing }}\right) \\
Q_{\text {condens }}=m_{\text {condens }} \cdot C_{p, \text { condens }} \cdot\left(t_{\text {condens }}-t_{\text {washing }}\right)
\end{gathered}
$$

The energy demand for increasing the dew point temperature in each concept was calculated as the difference between the thermal energy of a stream at the outlet and the inlet of a device, taking the corresponding device's efficiency into account $(90 \%$ for the heater, $90 \%$ for the steam generator, $85 \%$ for the compressor and $90 \%$ for the pump $[30,31])$ :

$$
Q_{d e m}=\frac{Q_{d, o u t}-Q_{d, \text { in }}}{\eta}
$$

The energy cost was estimated for each tested concept, assuming that: (1) the flue gas compressor (concept 3) is driven by the electro motor, while (2) the heater and the steam generator (concepts 1, 2 and 4) use natural gas as fuel. The average electricity and the natural gas prices for German industries in 2017 were $0.127 € / \mathrm{kWh}$ and $0.026 € / \mathrm{kWh}$, respectively [32].

\section{Results and Discussion}

The effects of the dew point temperature of the water vapour in the flue gas $(\Theta)$ and the flow rate of the cooling water in the HE $\left(m_{w, i n}\right)$ on the recovered thermal energy $\left(Q_{R E}\right)$, the water temperature at the HE outlet $\left(t_{w, o u t}\right)$ and the condensate flow rate $\left(m_{\text {condens }}\right)$ were investigated for each concept described above. The fitting curves were created using the Origin ${ }^{\circledR} 2019$ by polynomial fit of the second order with $R^{2} \in$ [0.9882-1]. 


\subsection{Concept 1: Humidification of the Flue Gas Using Water}

In this concept, water $\left(\mathrm{t}=95^{\circ} \mathrm{C}\right.$ and $\left.\mathrm{p}=1.01 \mathrm{bar}\right)$ for humidification of the flue gas is sprayed directly into the flue gas stream. The computational results of the calculations, obtained for concept 1 , are presented in Figure 5.

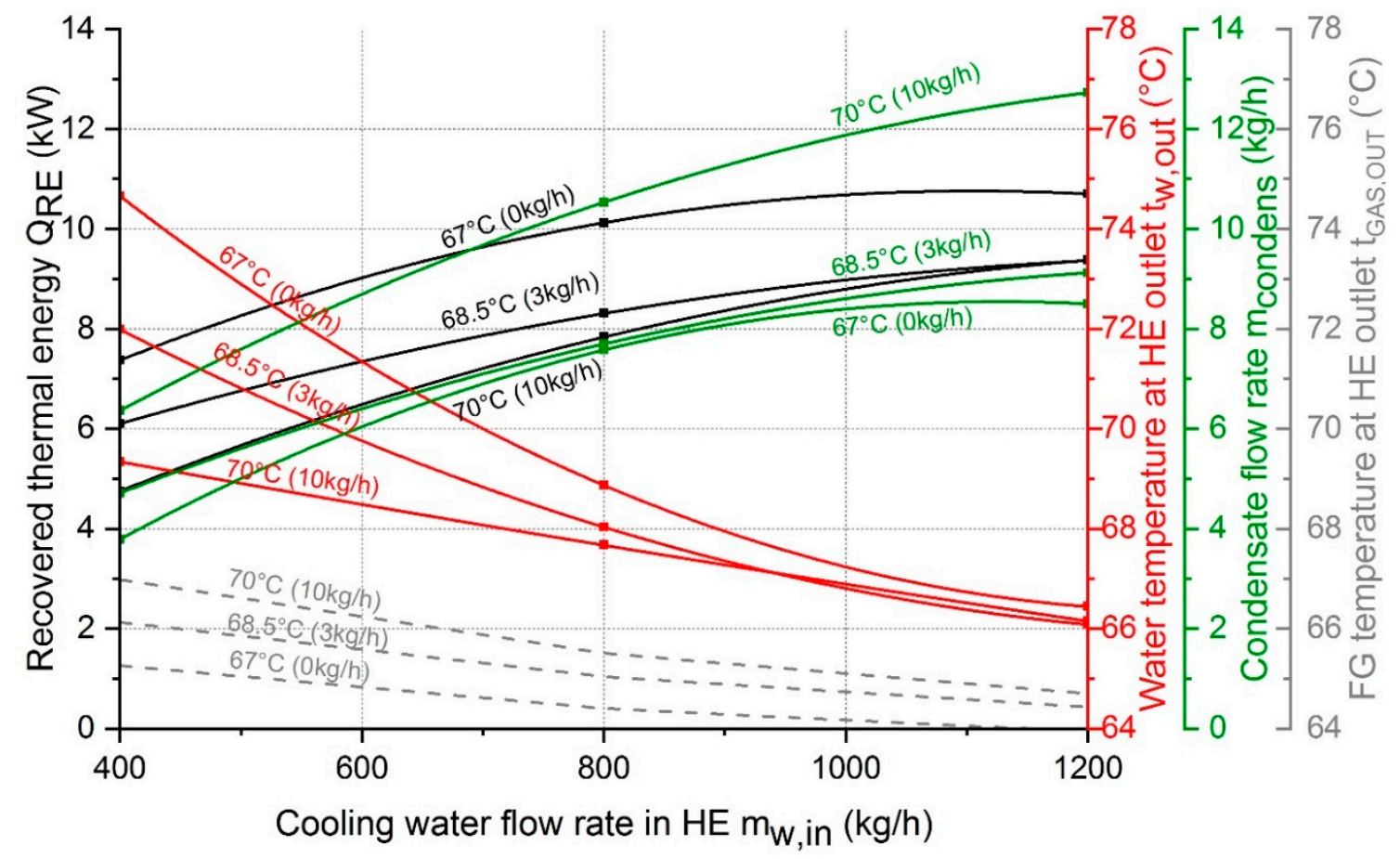

Figure 5. Influence of the cooling water flow rate in the heat exchanger (HE) and the dew point temperature on the recovered thermal energy (black lines), the water temperature at the HE outlet (red lines), the condensate flow rate (green lines) and the flue gas temperature at the HE outlet (gray lines) for concept 1 .

Increasing the flow rate of sprayed water $(0,3,10 \mathrm{~kg} / \mathrm{h})$ leads to an increase of the dew point temperature from $67^{\circ} \mathrm{C}$ (no water added) to $70^{\circ} \mathrm{C}$ (water addition of $10 \mathrm{~kg} / \mathrm{h}$ ). The relatively low temperature increase of $\Delta \mathrm{T}=3{ }^{\circ} \mathrm{C}$ can be attributed to the negligible rise in the water content of the flue gas. On the other hand, a further increase of the sprayed water amount above $10 \mathrm{~kg} / \mathrm{h}$ is limited by the ability of the flue gas to evaporate the sprayed water.

The increase of the dew point temperature from $67^{\circ} \mathrm{C}$ to $70{ }^{\circ} \mathrm{C}$ results in the $8 \%$ reduction of the water temperature at the outlet of the HE $\left(t_{w, \text { out }}\right)$ for $400 \mathrm{~kg} / \mathrm{h}$ flow rate of cooling water. This is due to the fact that in case of the low flow rate of cooling water, the transferred heat is mostly sensible and, therefore, higher for the flue gas with the lower dew point temperature. By increasing the flow rate of cooling water more condensate is generated, meaning that the transferred heat is both sensible and latent. The same explanation is applicable to the thermal energy recovery trend line, which increases with the increase of the cooling water flow rate.

Nevertheless, due to the low amount of the recovered thermal energy (maximum of $10.5 \mathrm{~kW}$ ) and unattainability of the high dew point temperature, this concept does not meet the goals of the research and is not recommended for the practical use in the investigated facility.

\subsection{Concept 2: Humidification of the Flue Gas Using Steam}

The computational results of the calculations, obtained for concept 2, are presented in Figure 6. Steam for the humidification purpose is supplied in this case at the temperature of $120^{\circ} \mathrm{C}$ and pressure of 1.01 bar. 


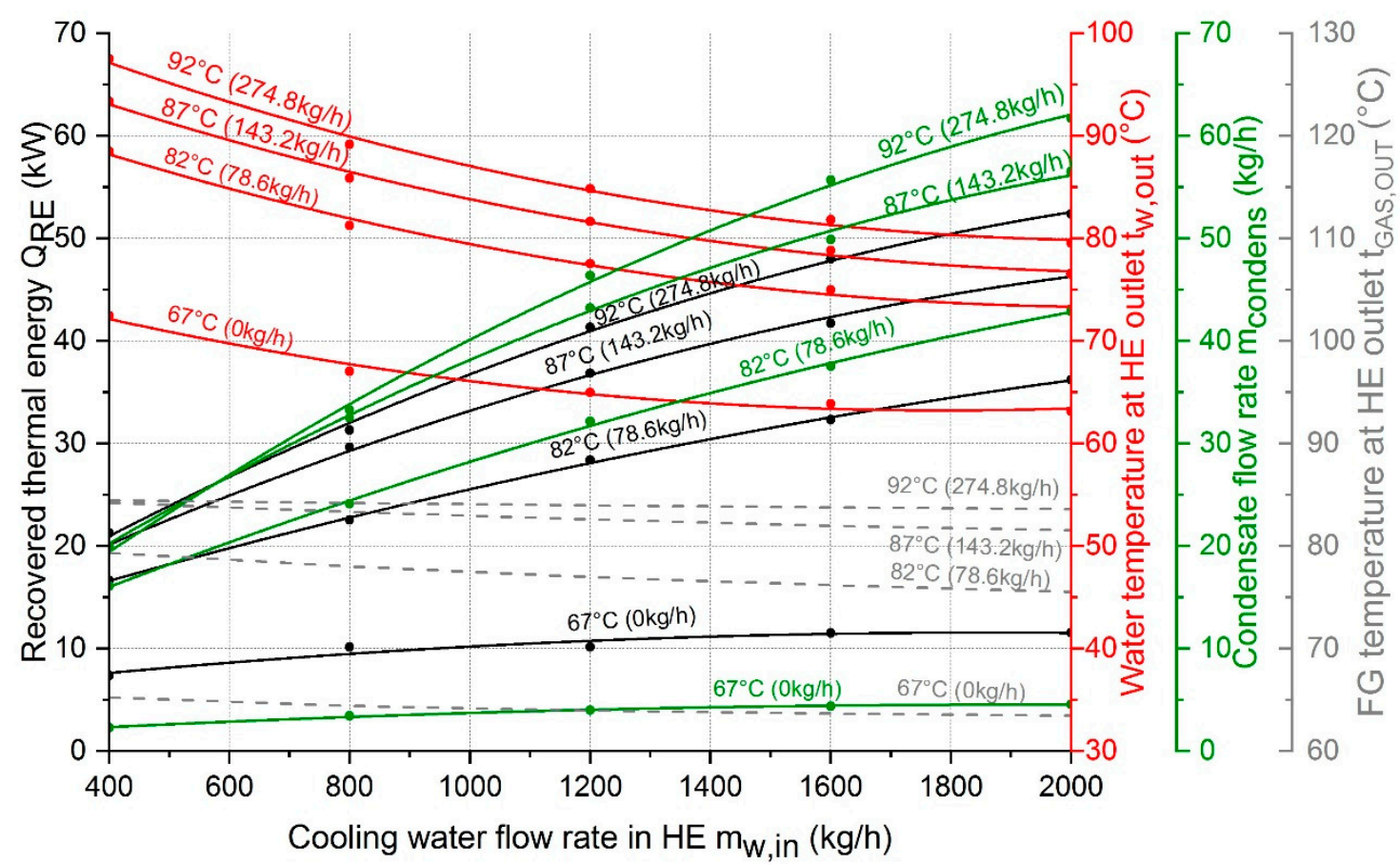

Figure 6. Influence of the cooling water flow rate in the HE and the dew point temperature on the recovered thermal energy (black lines), the water temperature at the HE outlet (red lines), the condensate flow rate (green lines) and the flue gas temperature at the HE outlet (gray lines) for concept 2.

The increase of the dew point temperature $\left(67,82,87\right.$ and $\left.92^{\circ} \mathrm{C}\right)$ is achieved by increasing the flow rate of the introduced steam $(0,78.6,143.2$ and $274.8 \mathrm{~kg} / \mathrm{h}$, respectively). As expected, this results in the increase of all investigated parameters. For the flow rate of cooling water of $2000 \mathrm{~kg} / \mathrm{h}$, the recovered thermal energy is increased by $80 \%$ (from 10 to $52 \mathrm{~kW}$ ), due to the enthalpy increase of the flue gas at the inlet of the HE caused by the steam humidification. The flow rate of condensate is increased by around $75 \%$ and reaches the maximum absolute value of $62 \mathrm{~kg} / \mathrm{h}$ for the case with $92{ }^{\circ} \mathrm{C}$ dew point and $2000 \mathrm{~kg} / \mathrm{h}$ flow rate of cooling water. Since by steam introduction, the enthalpy of the flue gas at the HE inlet increases, water which is passing through the HE is increasingly heated up. The temperature of water at the HE outlet increases on average by around $25 \%$, independent of the cooling water flow rate at the HE, with the increase of the dew point temperature.

The flow rate of the cooling water in the HE has the similar influence on investigated parameters compared to the previous concept with water humidification. Supplying more cooling water to the HE results in the release of latent heat from the flue gas, so the condensate flow rate and the recovered thermal energy show the intensive growth. On the other hand, the higher flow rate of the cooling water results in the decrease of the water temperature at the HE outlet. This follows from the fact that the same amount of the flue gas at the same conditions has to warm up the significantly (five times) increased amount of the cooling water in the HE.

\subsection{Concept 3: Compression of the Flue Gas}

In the third investigated concept the increase of the flue gas pressure $(1.01,1.92,2.33,2.83$ and $3.41 \mathrm{bar}$ ) results in the increase of the dew point temperature $\left(67,82,87,92\right.$ and $97^{\circ} \mathrm{C}$, respectively), whereas the water vapour content of the flue gas remains constant ( $17 \%$ mas). The computational results, obtained for concept 3 are shown in Figure 7.

The dependences of $Q_{R E}, t_{w, \text { out }}$ and $m_{\text {condens }}$ are qualitatively similar to the ones obtained in the concept with the steam humidification. However, the achieved values are higher in the case of steam humidification. For instance, the recovered thermal energy displays the rise while increasing the dew point temperature, but the maximum absolute value is $30 \mathrm{~kW}$ in the case of the flue gas compression, 
which is ca. $20 \mathrm{~kW}$ less than in the case of the steam humidification. This is because the flue gas contains four times less water vapour: $46.8 \mathrm{~kg} / \mathrm{h}$ in the case of the flue gas compression concept and $(46.8+143.2) \mathrm{kg} / \mathrm{h}$ in the case of the steam based humidification.

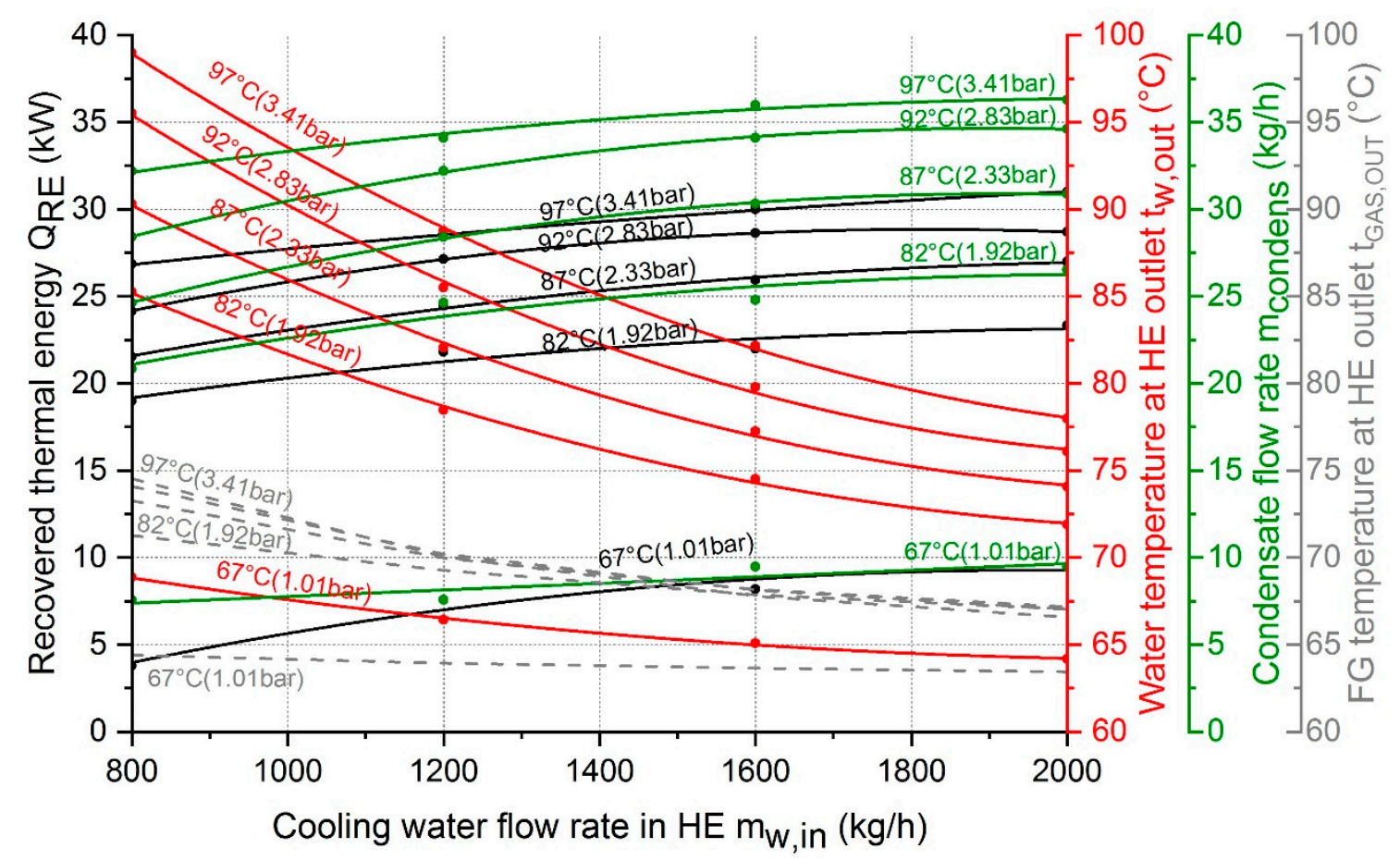

Figure 7. Influence of the cooling water flow rate in the HE and the dew point temperature on the recovered thermal energy (black lines), the water temperature at the HE outlet (red lines), the condensate flow rate (green lines) and the flue gas temperature at the HE outlet (gray lines) for concept 3.

Nevertheless, looking at the condensation rate, the pressure rise of the flue gas of around 2 bar (from 1.01 to $3.41 \mathrm{bar}$ ) leads to the $70 \%$ increase in the condensate flow rate.

The temperature of the flue gas is significantly increased during the isentropic compression and the high amount of the sensible heat is transferred to the water supplied to the HE. For this reason the water temperature at the outlet of the HE rises with the increase of the dew point temperature by around $30 \%$ for the low flow rate of the cooling water $(800 \mathrm{~kg} / \mathrm{h})$ and by around $17 \%$ for the high flow rate $(2000 \mathrm{~kg} / \mathrm{h})$.

\subsection{Concept 4: Usage of the Steam Ejector}

The modelling results for concept 4 (steam supply via the steam ejector) in comparison to concept 2 (steam supply via the steam generator) are presented in Figure 8. The comparison is eligible, due to the same flow rate of steam introduced in both cases, which amounts to $143.2 \mathrm{~kg} / \mathrm{h}$. While the humidification via the steam generator was performed by adding steam at $120^{\circ} \mathrm{C}$ and $1.01 \mathrm{bar}$, the steam ejector was supplied with steam at $160^{\circ} \mathrm{C}$ and 4 bar. In concept 2 , the dew point temperature was $87^{\circ} \mathrm{C}$, whereas in concept 4 the higher dew point temperature was reached, namely $91{ }^{\circ} \mathrm{C}$.

The process tendencies, corresponding to concepts 2 and 4, are qualitatively similar, but the target temperatures (dew point and cooling water outlet temperature) are higher in the case of the steam ejector. This is attributed to the fact that the usage of the steam ejector leads to the increase in both the water content and the pressure of the flue gas.

The condensate flow rate and the recovered thermal energy are almost the same in the case of the low flow rate of the cooling water $(400-1200 \mathrm{~kg} / \mathrm{h})$ for both concepts. In this case the condensate flow rate dependencies are similar and therefore, the recovered thermal energy is mainly influenced by the sensible heat of the flue gas. 
Increasing the cooling water flow rate further demonstrates the more noticeable difference between the two concepts. For $2000 \mathrm{~kg} / \mathrm{h}$ the recovered thermal energy and the condensate flow rate are around $8 \%$ and $12 \%$ higher in the case of the steam ejector usage, because steam is introduced at higher thermodynamic parameters.

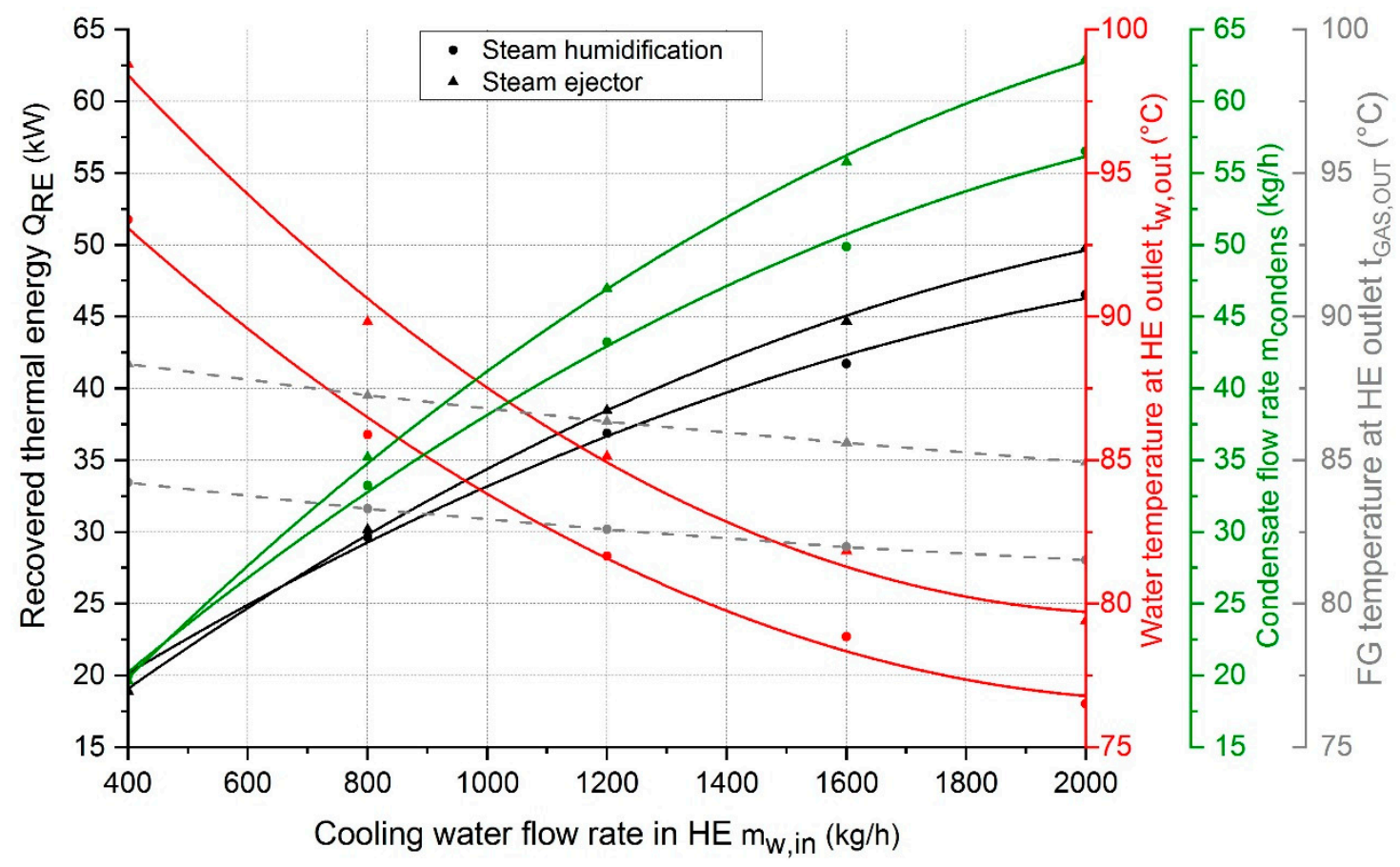

Figure 8. Comparison between the results calculated for concepts 2 and 4 . Influence of the cooling water flow rate in the HE on the recovered thermal energy (black lines), the water temperature at the HE outlet (red lines), the condensate flow rate (green lines) and the flue gas temperature at the HE outlet (gray lines).

The water temperature at the outlet of the $\mathrm{HE}$ by using the steam ejector is $10^{\circ} \mathrm{C}$ higher compared to the steam humidification case in the whole range of the cooling water flow rate. This follows from the fact that the flue gas at the inlet of the HE has higher temperature in the case of the steam ejector concept, therefore the flue gas transfers more sensible heat to the cooling water passing through the HE.

\subsection{Comparison of the Results of the Investigated Concepts}

The energy balance with the gain and the demand trend lines for concepts 2, 3 and 4, at the cooling water flow rate of $1200 \mathrm{~kg} / \mathrm{h}$, are shown in Figure 9. Concept 1 (humidification of the flue gas using water) is not considered, due to the relatively low increase in the dew point temperature.

During the humidification of the flue gas using steam (concept 2), additional energy input is required for the steam generator. In the concept with the compression of the flue gas (concept 3), additional energy input is required to run the flue gas compressor. In the case of the steam ejector usage (concept 4), additional energy is required by the pump, for the pressure rise of water, and by the steam generator, for the production of steam.

The analysis indicates that the humidification of the flue gas using steam (concept 2) is the most energy demanding process for increasing the dew point temperature. The energy demand of the steam generator rises with the dew point temperature increase, since the greater mass flow rate of water has to be evaporated in order to get the required amount of steam for injection into the flue gas. The concept with the steam ejector (concept 4 ) has the lower energy demand than concept 2, because the desirable dew point temperature is reached using the lower amount of steam but at the higher pressure. Moreover, the pump has a relatively high efficiency and is considered as the low-energy 
consuming equipment for increasing the pressure. In case of the third investigated concept, where the flue gas is compressed, the energy demand is the lowest of all three concepts. The reason is that the mass flow rate of the flue gas to the compressor remains constant for all of the investigated dew point temperatures. The maximum considered pressure increase by the compressor is about 2 bar (for increasing the dew point temperature from $67^{\circ} \mathrm{C}$ to $97^{\circ} \mathrm{C}$ ), which requires a relatively low isentropic work.

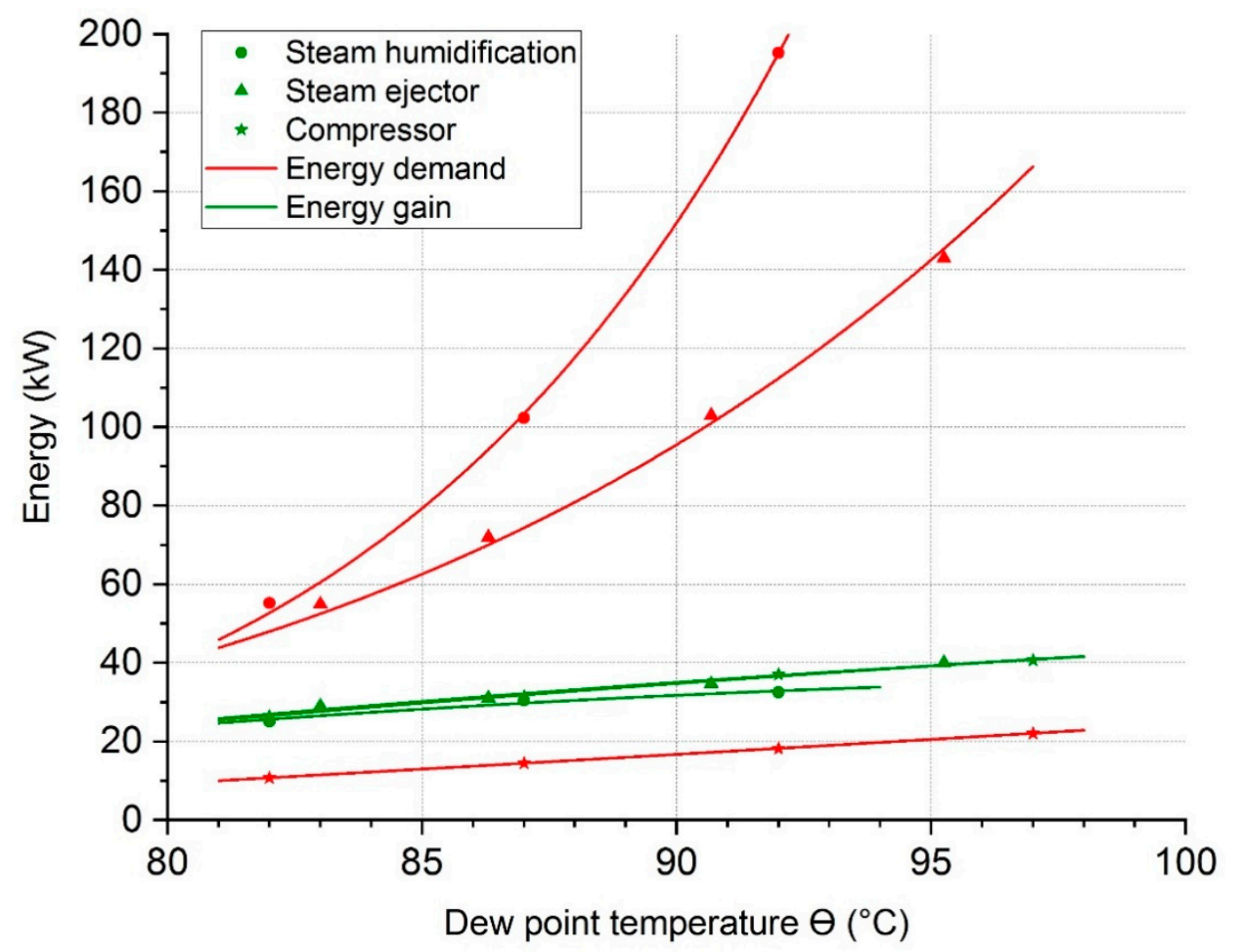

Figure 9. The energy demand and the energy gain for increasing the dew point temperature $(\Theta)$ for the investigated concepts.

Further analysis of the obtained results is related to the ratio of the recovered and additionally introduced energy. Since the energy gain stays almost the same for all investigated concepts, the conclusion is that only the third investigated concept, based on the flue gas compression, is of practical interest. In this case the energy gain exceeds the energy demand, therefore, the concept with compression is considered as the most promising for the energy recovery in the systems with the dew point temperature increase.

Cost analysis of the investigated concepts was conducted based on the current energy costs and additional energy demands of different concepts (Figure 10). The prices of different energy sources were introduced in chapter 2.6. The required investment costs including the prices of equipment were not taken into consideration.

As it was expected, the energy cost follows the trend of the energy demand, and grows as the dew point temperature increases. The growth of the energy cost per temperature degree for the steam humidification concept is especially steep, since the generation of the high amount of steam is coupled with the high energy demand. The energy cost can be reduced up to $35 \%$ (for the dew point temperature of $92^{\circ} \mathrm{C}$ ) by applying the steam ejector, which uses the lower amount of steam, but at higher pressure.

The energy cost in the case of the flue gas compression concept also increases, since the greater pressure is required for increasing the dew point temperature. Compared to two other concepts, concept 3 exhibits the lowest energy cost $(20,000 € /$ year $)$, which is half of the costs of concept 2 in the case of the dew point temperature of $92^{\circ} \mathrm{C}$. Nevertheless, the installation, the maintenance and the 
repair costs of the compressor are normally higher than the equipment used in the other proposed concepts and should be taken into account in the future work.

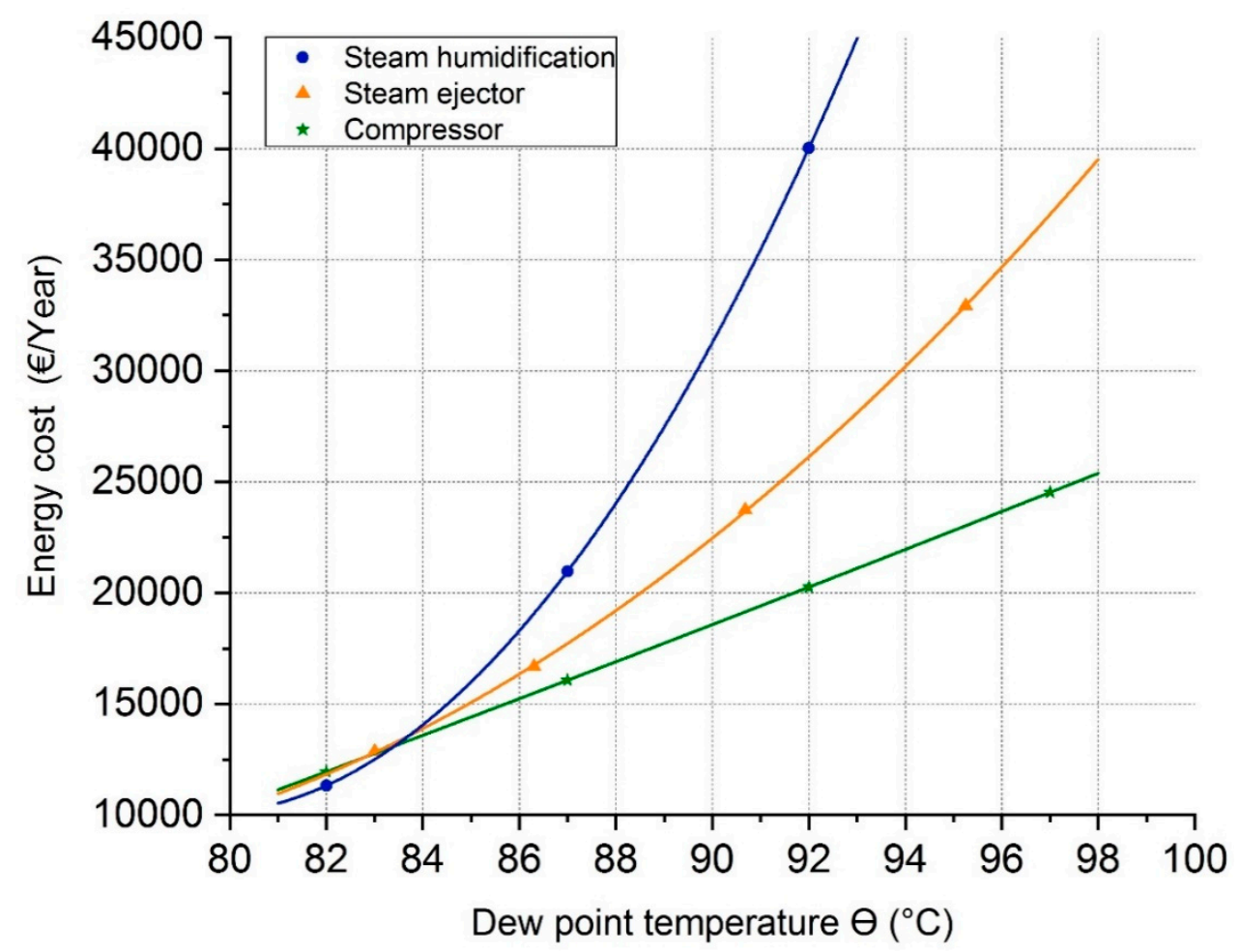

Figure 10. Estimated energy costs for the investigated concepts.

The potential practical application of the theoretical concepts investigated in this work is also related to several major challenges. The first one is an appropriate selection of the optimal method based on the actual size, requirements and properties of each specific facility. For example, all the calculations and considerations in this work are related to one specific industrial facility, namely the natural gas fired, tunnel baking oven. The limitations related to the investigated facility (composition, temperature and flow rate of the flue gas, fluid parameters at the inlet/outlet of the process components, etc.) influence most of the obtained results. Therefore, it is imperative to perform the similar analysis for each specific system of interest with its unique properties. The next technical challenge is to compensate for the eventual dynamic changes within the process. The presented work is based on the continuous industrial process with time independent process parameters which is often not the case. Although compensation of the dynamic process behavior is out of the scope of this work, the use of cognitive algorithms for the process management in connection to the dew point temperature increase, could result in the optimal use of the available potentials for the thermal energy recovery. Nevertheless, one of the major challenges for the practical implementation of the investigated techniques would probably be of the financial nature and related to the investment costs for the additional equipment. Taking into account the investment costs, the additional maintenance costs and the price of the low-temperature thermal energy in Germany, some of the simplified financial calculations, not presented in this work, indicate that most of the investigated processes are financially justified only for the larger facilities and pay-off periods of 20-30 years. Therefore, a full economic analysis for the considered concepts will be part of a future detailed investigation.

\section{Conclusions}

Recovering both the sensible and latent heat is part of the energy efficiency optimization of every process that has thermal energy dissipating with the flue gas. Essential relevance is related to the industrial processes where flue gases are rich in water vapour (e.g., baking, textile, pulp and paper 
industries). Cooling the flue gas below the water vapour dew point temperature in a shell-and-tube heat exchanger, leads to the condensation of the water vapour and to the release of the sensible and latent heat. In order to use this energy as process heat, the increase of the usually low dew point temperatures $\left(40-60{ }^{\circ} \mathrm{C}\right)$ to the higher levels $\left(80-95^{\circ} \mathrm{C}\right)$ is of special interest.

The increase of the dew point temperature of the water vapour contained in the flue gas, leads to the increase of the temperature level of the cooling fluid and the condensate. In this way, these otherwise waste streams can be further used within an industrial process, thus improving its energy efficiency.

The present study was focused on the investigation of four concepts for the increase of the dew point temperature of the industrial flue gas: humidification of the flue gas using water, humidification of the flue gas using steam, compression of the flue gas and the usage of the steam ejector. All the calculations and considerations in this work are related to one specific industrial facility, namely the natural gas fired, tunnel baking oven. The process modelling was performed using the commercial software Aspen ${ }^{\circledR}$. For each considered concept the effects of the dew point temperature and the cooling water flow rate in the HE on the recovered thermal energy, the water temperature at the HE outlet and the condensate flow rate were investigated.

The major conclusions for the considered concepts are summarized as follows:

- The increase of the dew point temperature above $90^{\circ} \mathrm{C}$ is possible by the steam humidification, compression of the flue gas and using the steam ejector.

- The humidification of flue gas using water is not recommended, due to the relatively low thermal energy recovery level (maximum of $10 \mathrm{~kW}$ is achieved) and the negligible increase in the dew point temperature (up to $70^{\circ} \mathrm{C}$ ) in comparison to other tested concepts.

- Although the steam humidification shows the highest potential for the thermal energy recovery, it is also the most energy demanding and, consequently, the most expensive process, in the case when the steam has to be specially produced for the dew point temperature increase. When this low parameter steam is available as a waste product, the investigated concept gains on its importance.

- In the steam humidification concept the maximum of $52 \mathrm{~kW}$ of the recovered thermal energy is achieved and the flow rate of the condensate is increased by app. $75 \%$ at $m_{w, i n}=2000 \mathrm{~kg} / \mathrm{h}$. The maximal calculated dew point temperature is $92^{\circ} \mathrm{C}$. The energy demand of the steam generator increases with the dew point temperature increase, since the greater water mass flow rate has to be heated and evaporated, in order to get the required amount of steam.

- Using the steam ejector leads to the increase in both the water content and pressure of the flue gas, due to the geometry of the device. Therefore, the recovered thermal energy and the condensate flow rate are around $8 \%$ and $12 \%$ higher compared to the steam humidification concept. Yet, the energy demand exceeds the energy gain, making this concept not suitable for the use in a thermal energy recovery cycle, in the case when there is no waste steam available in the facility.

- Both from the energetic and economic point of view, the compression of the flue gas has the highest potential, as the energy gain exceeds the energy demand and the energy cost is the lowest out of all the investigated methods. Although the low required pressure increase of app. 2 bar corresponds to the relatively low isentropic work by the compressor, a detailed economic analysis should be performed, taking into account the equipment price, the installation and the maintenance costs for each concrete industrial facility.

- The concept with the flue gas compression will be the subject of further investigations, in combination with the Organic Rankine Cycle and the absorption refrigerator.

Author Contributions: Conceptualization, N.F., V.J., A.Z.-R. and A.D.; Methodology, N.F., V.J. and P.A.; Validation, P.A.; Investigation, P.A., N.F.; Resources, A.D.; Data Curation, P.A., N.F., V.J., A.Z.-R. and M.J.K.; Writing-Original Draft Preparation, N.F., P.A., A.Z.-R. and V.J.; Writing-Review and Editing, N.F., V.J., A.Z.-R., M.J.K. and P.A.; Software, P.A. and M.J.K.; Visualization, P.A. and N.F.; Supervision, N.F., V.J.; Funding acquisition, N.F., V.J., A.D.

Funding: This research received no external funding. 
Acknowledgments: The authors gratefully acknowledge the financial support of the German Academic Exchange Service (DAAD), and the funding of the Erlangen Graduate School in Advanced Optical Technologies (SAOT) by the German Research Foundation (DFG) in the framework of the German excellence initiative. We also acknowledge the support by Deutsche Forschungsgemeinschaft and Friedrich-Alexander-Universität Erlangen-Nürnberg (FAU) within the funding programme Open Access Publishing.

Conflicts of Interest: The authors declare no conflict of interest. The funders had no role in the design of the study; in the collection, analysis, or interpretation of data; in the writing of the manuscript, or in the decision to publish the results.

\section{Nomenclature}

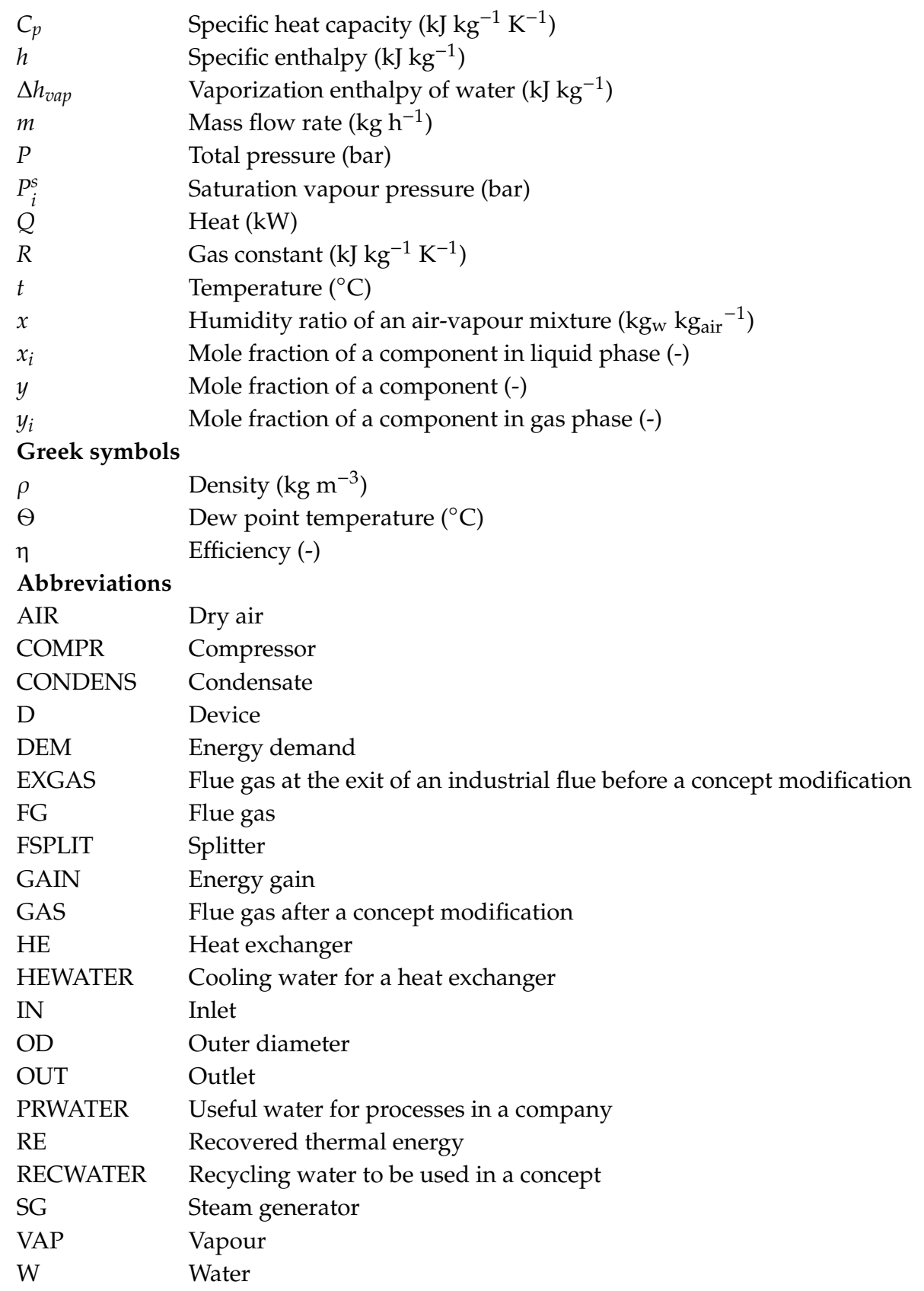




\section{References}

1. Hu, Y.; Gao, Y.; Lv, H.; Xu, G.; Dong, S. A New Integration System for Natural Gas Combined Cycle Power Plants with $\mathrm{CO}_{2}$ Capture and Heat Supply. Energies 2018, 11, 3055.

2. Schwabe, K.; Walsdorf-Maul, M.; Schaudienst, F.; Vogdt, F.U. Using Waste Heat for Sustainable Manufacturing Based on the Example of a Conventional Industrial Bakery. Int. J. Mater. Mech. Manuf. (IJMMM) 2013, 274-277. [CrossRef]

3. Terhan, M.; Comakli, K. Design and economic analysis of a flue gas condenser to recover latent heat from exhaust flue gas. Appl. Therm. Eng. 2016, 100, 1007-1015. [CrossRef]

4. Xu, G.; Huang, S.; Yang, Y.; Wu, Y.; Zhang, K.; Xu, C. Techno-economic analysis and optimization of the heat recovery of utility boiler flue gas. Appl. Energy 2013, 112, 907-917. [CrossRef]

5. Aneke, M.; Agnew, B.; Underwood, C.; Wu, H.; Masheiti, S. Power generation from waste heat in a food processing application. Appl. Therm. Eng. 2012, 36, 171-180. [CrossRef]

6. Che, D.; Da, Y.; Zhuang, Z. Heat and mass transfer characteristics of simulated high moisture flue gases. Heat Mass Transf. 2005, 41, 250-256. [CrossRef]

7. Wang, D.; Bao, A.; Kunc, W.; Liss, W. Coal power plant flue gas waste heat and water recovery. Appl. Energy 2012, 91, 341-348. [CrossRef]

8. Bajpai, P. Pulp and Paper Production Processes and Energy Overview. In Pulp and Paper Industry; Elsevier: Amsterdam, The Netherlands, 2016.

9. Hasanbeigi, A.; Price, L. A review of energy use and energy efficiency technologies for the textile industry. Renew. Sustain. Energy Rev. 2012, 16, 3648-3665. [CrossRef]

10. Jank, R.; Schulte, S. Verfahren zur Energiegewinnung aus Wasserdampf enthaltenden Schwaden und Vorrichtung zur Durchführung dieses Verfahrens. European Patent No. WO2017064036, 20 April 2017.

11. Song, C.; Pan, W.; Srimat, S.T.; Zheng, J.; Li, Y.; Wang, Y.-H.; Xu, B.-Q.; Zhu, Q.-M. Tri-reforming of Methane over Ni Catalysts for $\mathrm{CO}_{2}$ Conversion to Syngas With Desired $\mathrm{H}_{2} / \mathrm{CO}$ Ratios Using Flue Gas of Power Plants Without $\mathrm{CO}_{2}$ Separation. In Carbon Dioxide Utilization for Global Sustainability, Proceedings of the 7th the International Conference on Carbon Dioxide Utilization, Seoul, Korea, 12-16 October 2003; Elsevier: Amsterdam, The Netherlands, 2004; pp. 315-322.

12. Osakabe, M. Heat exchanger for latent heat recovery. Mech. Eng. Rev.-Bull. JSME 2015, 2, 1-24. [CrossRef]

13. Zhao, S.; Yan, S.; Wang, D.K.; Wei, Y.; Qi, H.; Wu, T.; Feron, P.H.M. Simultaneous heat and water recovery from flue gas by membrane condensation: Experimental investigation. Appl. Therm. Eng. 2017, 113, 843-850. [CrossRef]

14. Law, R.; Harvey, A.; Reay, D. Opportunities for low-grade heat recovery in the UK food processing industry. Appl. Therm. Eng. 2013, 53, 188-196. [CrossRef]

15. Hung, T.C.; Shai, T.Y.; Wang, S.K. A review of organic rankine cycles (ORCs) for the recovery of low-grade waste heat. Energy 1997, 22, 661-667. [CrossRef]

16. Tchanche, B.F.; Lambrinos, G.; Frangoudakis, A.; Papadakis, G. Low-grade heat conversion into power using organic Rankine cycles-A review of various applications. Renew. Sustain. Energy Rev. 2011, 15, 3963-3979. [CrossRef]

17. Ziegler, F. EnEff Wärme: Absorptionskältetechnik für Niedertemperaturantrieb—Grundlagen und Entwicklung von Absorptionskältemaschinen für die fernwärme-und solarbasierte Kälteversorgung. In Abschlussbericht; Technische Universität Berlin Fakultät III-Prozesswissenschaften: Berlin, Germany, 2013.

18. Offizielles Stadtportal für die Hansestadt Hamburg. Solares Kühlen für Büro- und Dienstleistungsgebäude, Österreichisches Forschungs-und Prüfzentrum Arsenal Ges.m.b.H. Available online: https://www.hamburg. de/contentblob/1356374/8760da9f3d940e22e7f926723591eae7/data/solare-kuehlung.pdf (accessed on 25 March 2019).

19. U.S. Department of Energy. Waste Heat Reduction and Recovery for Improving Furnace Efficiency, Productivity and Emissions Performance. Available online: https:/www.energy.gov/sites/prod/files/2014/05/ f15/35876.pdf (accessed on 25 March 2019).

20. Mukherjee, S.; Asthana, A.; Howarth, M.; Mcniell, R. Waste heat recovery from industrial baking ovens. Energy Procedia 2017, 123, 321-328. [CrossRef] 
21. EcoStep. Energieeffizienz in Bäckereien-Energieeinsparungen in Backstube und Filialen, ttz Bremerhaven. Available online: http://www.ecostep-online.de/cms_uploads/files/eneff_baeckerei_-_leitfaden_-_juli_2014. pdf (accessed on 25 March 2019).

22. Jana, K.; De, S. Utilizing waste heat of the flue gas for post-combustion $\mathrm{CO}_{2}$ capture-A comparative study for different process layouts. Energy Sources Part A Recovery Util. Environ. Eff. 2016, 38, 960-966. [CrossRef]

23. Luyben, W.L. Heat exchanger simulations involving phase changes. Comput. Chem. Eng. 2014, 67, $133-136$. [CrossRef]

24. Duan, W.; Yu, Q.; Wang, K.; Qin, Q.; Hou, L.; Yao, X.; Wu, T. ASPEN Plus simulation of coal integrated gasification combined blast furnace slag waste heat recovery system. Energy Convers. Manag. 2015, 100, 30-36. [CrossRef]

25. Ishaq, H.; Dincer, I.; Naterer, G.F. New trigeneration system integrated with desalination and industrial waste heat recovery for hydrogen production. Appl. Therm. Eng. 2018, 142, 767-778. [CrossRef]

26. Mazzoni, S.; Arreola, M.J.; Romangoli, A. Innovative Organic Rankine arrangements for Water Savings in Waste Heat Recovery Applications. Energy Procedia 2017, 143, 361-366. [CrossRef]

27. Hu, H.W.; Tang, G.H.; Niu, D. Experimental investigation of convective condensation heat transfer on tube bundles with different surface wettability at large amount of noncondensable gas. Appl. Therm. Eng. 2016, 100, 699-707. [CrossRef]

28. Towler, G.; Sinnott, R. Chemical Engineering Design: Principles, Practice, and Economics of Plant and Process Design, 2nd ed.; Butterworth-Heinemann: Waltham, MA, USA, 2013.

29. Incropera, F.P.; Dewitt, D.P.; Bergman, T.L.; Lavine, A.S. Principles of Heat and Mass Transfer, 7th ed.; John Wiley \& Sons: Hoboken, NJ, USA, 2011.

30. Baehr, H.D.; Kabelac, S. Thermodynamik; Springer Vieweg: Berlin, Germany, 2012.

31. Spirax Sarco. Grundlagen der Dampf-und Kondensattechnologie. Available online: http://www.spiraxsarco. com/global/de/Resources/Documents/Grundlagen-der-Dampf-und-Kondensattechnologie.pdf (accessed on 25 March 2019).

32. Statistisches Bundesamt (Destatis). Data on Energy Price Trends, Long-Time Series from January 2000 to March 2018. Available online: https://www.destatis.de (accessed on 25 March 2019).

(C) 2019 by the authors. Licensee MDPI, Basel, Switzerland. This article is an open access article distributed under the terms and conditions of the Creative Commons Attribution (CC BY) license (http://creativecommons.org/licenses/by/4.0/). 